\title{
Assessment of Veterinary Extension Service and Public Perception on Major Infectious and Zoonotic Disease at Robe Veterinary Clinic of Bale Zone, Oromia, Ethiopia
}

\section{Sultan Abda Neja ( $\square$ sultanabda@gmail.com )}

Hawassa University Faculty of Veterinary Medicine, P.O. Box 05, Hawassa, Ethiopia

\section{Amir Adam}

Hawassa University Faculty of Veterinary Medicine, P.O. Box 05, Hawassa, Ethiopia

\section{Research Article}

Keywords: Bale, Robe, Vaccination, Veterinary Extension, Zoonotic disease

Posted Date: December 7th, 2021

DOI: https://doi.org/10.21203/rs.3.rs-1120325/v1

License: (c) (1) This work is licensed under a Creative Commons Attribution 4.0 International License. Read Full License 


\section{Abstract \\ Background}

A survey-based cross-sectional study was conducted from April to August 2021 to assess veterinary extension service and public perception on major infectious and zoonotic diseases at Robe veterinary clinic. 384 animal owners who brought their animals for treatment were interviewed.

\section{Results}

The result indicated that $70.8 \%$ of respondents had no veterinary extension service. The majority (88\%) had no access to the veterinary consultant. Although $51.6 \%$ of them used Al, only $7.8 \%$ of them know how to detect estrous. The most frequently known zoonotic diseases were Rabies (96.6\%) followed by Anthrax (33.07\%), and Tuberculosis (4.2\%). Out of the $96.6 \%$ of respondents that replied to know about Rabies, $51.8 \%$ of them mentioned the disease can be transmitted only through dog biting while $14.8 \%$ of them say through biting and contact with saliva. Likewise, only $43.3 \%$ of respondents perceive that Anthrax is transmitted through ingestion, whereas $85 \%$ of them mentioned Tuberculosis can be transmitted from animal to humans only through inhalation. Although most animal owners prefer early treatment of animals in the veterinary clinic, there are also practices of traditional animal treatment. Remarkable only $16.4 \%$ and $24.7 \%$ of respondents know the importance of vaccination and slaughterhouse respectively. $93.8 \%$ and $94.8 \%$ of them still consume raw milk and meat respectively.

\section{Conclussion}

: The finding indicates that veterinary extension services are a neglected venture; the knowledge, attitude, and practice on prevention and control of major infectious and zoonotic diseases are still insufficient. Therefore there should be multidisciplinary one-health approach in educating the community about infectious and zoonotic diseases.

\section{Background}

Extension services provide farmers with important information, such as patterns in crop prices, new seed varieties, animal management, and marketing[1]. As awareness of previous technologies and knowledge produces actual demand, it gives signal to the input delivery systems thus, extension and input distribution systems are kept to be reciprocally reinforcing [2]. An ideal extension service system also provides feedback from farmers to research centers [3]. Extension activities are often aimed to improve farmers' knowledge, attitude and practice to use of their resources and albeit technologies that are available to them [4]. In this regard, the term 'veterinary extension' has been defined as an informal education provided by veterinarians on animal health and zoonosis to the rural livestock owners [5]. 
Livestock sector in Ethiopia is an integral part of agriculture, accounting for about $45 \%$ of the total value of agricultural production and supporting the livelihoods of over $65 \%$ human population. More than $80 \%$ of the population lives in rural areas in contact with livestock out of which $30 \%$ of them are still in poverty $[6,7]$. In terms of livestock population, Ethiopia leads African countries with an estimated 59 million cattle, 30 million sheep, 23 million goats, 1 million camels, and 57 million poultry, 11 million equines and a small number of pigs [8]. On top of their use as a source of foods, product of comodities and services to the people, the livestock also provides $10 \%$ the countries export earnings, mainly through live animal export. The total supply of animal source foods in the country, including net trade, translates into a per capita consumption of $9 \mathrm{~kg}$ meat, 56.2 liters of milk and about 4 eggs per year. Cattle products, beef and cow milk contribute to almost $80 \%$ of all meat and milk consumption. Market transactions are largely in urban areas as self-consumption dominates in rural areas [9]

In Ethiopia, where animals are used for transportation, farming, cloths, source of fuel and dietary protein, there is very close contact among humans, animals, wildlife and the surrounding environment. In the absence of appropriate animal and human health care and preventative health services, this crosscontact creates public health risks via zoonotic disease transmission with enormous economic consequences $[10,11]$.

Health extension services for knowledge transfer from professionals to society play an important role in the prevention and control of infectious diseases. Before 2015 in Ethiopia, there was no well-developed national strategy to teach society about animal health and zoonosis. This important gap created a lack of perception of society about the disease. Later in 2015 multidisciplinary One-Health initiative workshops developed a list of Rabies, anthrax, brucellosis, leptospirosis and echinococcosis as the top five priority zoonotic diseases the greatest national concern in Ethiopia[12].

Veterinary health extension is a sector of animal health service to the community that can provide information through continuing education, informal training, consultations and materials to practitioners as well as animal health packages to the animal owners. Although improvement in animal health care correlates with better public health care, the control of zoonotic disease in Ethiopia has been partially neglected between veterinary and medical professionals $[5,13]$. Currently, the number of universities that produce veterinary professionals and veterinary infrastructures that could provide the platform for animal health extension services in the country. But still, the extension service so far given by the veterinarian is very limited and mainly targets the convectional treating sick animals, providing seasonal vaccination and occasionally delivery of artificial insemination. Chemotherapy becoming the routine attempt for treatment and control of animal disease; which usually end-up with antibiotic resistance [5]. There is a limited attempt by the veterinarian to transfer the knowledge about risks of animal disease transmission to the animal owners and community at large [14].

Zoonosis is an infectious disease that is transmitted from animals to humans. Of the microbial diseases affecting humans $61 \%$ are zoonotic [15]. The transmission may occur through direct contact with the animal, through vectors, or food or water contamination. Globally, zoonosis is said to account for $75 \%$ of 
all emerging pathogens $[16,17]$. The impact of zoonotic diseases on society includes animal and productivity loss, livelihood income loss and human health burden which further causes societal and economic loss [18]. There is high zoonotic disease health problem with many farmers still practicing poor livestock production $[19,20]$.

The control strategies for zoonotic diseases largely rely on the creation of public health awareness. In a resource-scarce developing country like Ethiopia, improving knowledge, attitude and practice of animal owners about infectious disease and zoonosis is critical to contain the spread of zoonotic diseases [21, 22]. In this regard, veterinarians are one of the key people in multidisciplinary and community-based health services. They could able to deliver veterinary extension services to animal owners. However, particularly in Ethiopia, there are no clear policies and allocated veterinary professional positions that teach the community about primary animal health care. Hence the present study was intended to assess the current status of veterinary extension service as well as public perception on major infectious and zoonotic diseases at Robe veterinary clinic of Bale zone.

\section{Material And Method}

\section{Study Area}

Robe, also called Bale-Robe, is a town located in Sinana district of the Bale Zone, Oromia Regional State, Ethiopia. It is one of the consistently surplus producer zones of the region. The capital city of the zone, Robe town is located about 430 kilometers from Ethiopia's capital Addis Ababa. It has a latitude and longitude of $7^{\circ} 7^{\prime} \mathrm{N} 40^{\circ} 0^{\prime} \mathrm{E}$ with an elevation of 2,492 meters $(8,176 \mathrm{ft})$ above sea level. Robe receives a relatively high amount of rainfall which is balanced in distribution pattern. According to available data, the mean annual rainfall ranges from $590 \mathrm{~mm}$ in the summer and $560 \mathrm{~mm}$ in the winter season. The area is highly populous, highly fertile and suitable for agricultural activities. The 2007 national census reported a total population for Robe of 44,382, of whom 22,543 were men and 21,839 were women[23].

\section{Study population}

All population brought their animal for diagnosis to Bale Robe veterinary clinic having different health problems during the study periods were considered as the study population.

\section{Study design}

A questionnaire-based cross-sectional study design was employed from April to August 2021 to assess the perception of the public on infectious disease and zoonotic diseases in Robe town of Bale zone, Oromia regional state. A structured and pre-tested questionnaire format was used.

\section{Sample size determination}

The sample size was determined based on derivation sample size [25]. 


\section{$\mathrm{N}=\underline{1.962 .} \operatorname{Pexp}(1-\mathrm{Pexp})$ \\ $d^{2}$}

Where

$\mathrm{N}=$ required sample size

exp= expected prevalence

$d=$ desired absolute precision

\section{Data collection}

\section{Questionnaire survey}

A detailed and organized questionnaire format was designed in an attempt to generate baseline information related and used for the face-to-face interview to evaluate the current Veterinary extension service status, perception of the community about the common and major infectious animal disease and zoonotic disease [26]. The questionnaire contains questions that can evaluate the perception of the respondents about zoonotic and infectious disease's importance, their transmission cycle and major clinical signs in humans and animals. In addition, animal owner perception and practice on the prevention and control of the disease were accessed.

\section{Data management and analysis}

The collected data were stored in the Excel Microsoft (MS excel 2007) and descriptive statistics and chisquare $(\chi 2)$ correlation analysis were performed using Statistical Program of Social Sciences (SPSS) version 16.0 software packages (SPSS Inc, Chicago, IL, USA). For all analysis performed, $95 \% \mathrm{Cl}$ and $\mathrm{P}$ value $<0.05$ was set for statistical significance of an estimate.

\section{Result}

\section{Socio-demographic characteristics of the respondents}

From Table 1, the majority of respondents were male $(78.1 \%)$ and the remaining $(21.9 \%)$ are female. The maximum and minimum Ages were (68) and (16) years. Concerning marital and education status, (64.3\%) of the respondents are married followed by unmarried $(28.4 \%)$ and $(20.6 \%)$ of the respondents are illiterate. Most of the respondents that participated in this study were farmers and merchants in which account for a proportion of $(40.1 \%)$ and $(33.3 \%)$ respectively. The highest number of the respondents $(65.4 \%)$ had come from around robe. 
Table 1

Socio-demographic characteristics of the respondents

\begin{tabular}{|llll|}
\hline Kebele & Kebele 01 & $\mathbf{2 1}$ & $\mathbf{5 . 5 \%}$ \\
\hline Kebele 02 & $\mathbf{3 8}$ & $\mathbf{9 . 9 \%}$ \\
\hline Kebele 03 & $\mathbf{4 5}$ & $\mathbf{1 1 . 7 \%}$ \\
\hline Kebele 04 & $\mathbf{2 9}$ & $\mathbf{7 . 6 \%}$ \\
\hline Around Robe & $\mathbf{2 5 1}$ & $\mathbf{6 5 . 4 \%}$ \\
\hline Sex & Male & 300 & $78.1 \%$ \\
\hline Female & 84 & $21.9 \%$ \\
\hline Marital status & Less than 20 & 9 & $2.3 \%$ \\
\hline 20 to 40 & 213 & $55.5 \%$ \\
\hline Above 40 & 162 & $42.2 \%$ \\
\hline Married & 247 & $64.3 \%$ \\
\hline Divorced & 18 & $4.7 \%$ \\
\hline Unmarried & 109 & $28.4 \%$ \\
\hline Widowed & 10 & $2.6 \%$ \\
\hline Illiterate & 79 & $20.6 \%$ \\
\hline Read and write & 109 & $28.4 \%$ \\
\hline Primary school & 115 & $29.9 \%$ \\
\hline Secondary school & 63 & $16.4 \%$ \\
\hline College and university & 18 & $4.7 \%$ \\
\hline Sarmer & 154 & $40.1 \%$ \\
\hline Merchant & 128 & $33.3 \%$ \\
\hline Employee & 17 & $4.4 \%$ \\
\hline Housewife & 29 & $7.6 \%$ \\
\hline Daily labor & 50 & $13 \%$ \\
\hline Students & 6 & 1.6 \\
\hline
\end{tabular}

\section{Perception of respondents about veterinary extension service and production management practice}


The highest number of the respondents (44\%) had owned mixed-type livestock and followed by only cattle (30.5\%) and shoats (7.8\%). The fundamental questions for this study were to find out whether the respondents were trained about animal production, animal management, and animal health and how to control the animal disease. As shown in (Table 2 ) results reveals respondents $(66.1 \%)$ and $(70.8 \%)$ were not trained, which indicates that the extension service in the study area was poor. Regarding the presence of consultants in the study area, most of the respondents (88.5\%) had no professionals who had been consulted them about animal health and management.

Analysis of the attitude of respondents toward extension services indicates that all of the respondents $(100 \%)$ are in support of agricultural extension service although (99\%) of the respondents keep their animal sanitation and health by cleaning their animal house. The major type of feed source for their animals mentioned by the respondents was concentrated plus grazing (53.6\%) natural pasture (grazing) also used in the study area (31.2\%). Regarding the estrous cycle (92.2\%) of the respondents do not know how to detect the early estrous sign and only half (51.6\%) of respondents bring their animals to the veterinary clinic at the proper time in search of the Al service. 
Table 2

Veterinary extension service and production management practice in the area

\begin{tabular}{|c|c|c|c|}
\hline Variable & Category & Frequency & $\begin{array}{l}\text { Percent } \\
(\%)\end{array}$ \\
\hline \multirow[t]{10}{*}{ Animals owned } & Cattle & 117 & 30.5 \\
\hline & Sheep & 30 & 7.8 \\
\hline & Goat & 23 & 6 \\
\hline & Horse & 9 & 2.3 \\
\hline & Mule & 1 & 0.3 \\
\hline & Donkey & 1 & 0.3 \\
\hline & sheep and goat & 30 & 7.8 \\
\hline & Equine & 4 & 1 \\
\hline & Cattle sheep and goat & 134 & 34.9 \\
\hline & Equine cattle & 35 & 9.1 \\
\hline \multirow[t]{2}{*}{ Breed } & Local & 310 & 80.7 \\
\hline & Exotic & 74 & 19.3 \\
\hline \multirow{3}{*}{$\begin{array}{l}\text { Trained about animal production and } \\
\text { management }\end{array}$} & Yes & 130 & 33.9 \\
\hline & No & 254 & 66.1 \\
\hline & Total & 384 & 100 \\
\hline \multirow[t]{2}{*}{ Trained about animal health } & Yes & 112 & 29.2 \\
\hline & No & 272 & 70.8 \\
\hline \multirow[t]{2}{*}{ clean the animal house } & Yes & 380 & 99 \\
\hline & No & 4 & 1 \\
\hline \multirow[t]{2}{*}{ Presence of consultant } & Yes & 44 & 11.5 \\
\hline & No & 340 & 88.5 \\
\hline \multirow{2}{*}{$\begin{array}{l}\text { The necessity of animal health extension } \\
\text { service }\end{array}$} & Yes & 100 & 100 \\
\hline & No & 0 & 0 \\
\hline \multirow[t]{3}{*}{ Feed type } & Concentrate & 13 & 3.4 \\
\hline & Roughage & 35 & 9.1 \\
\hline & Grazing & 15 & 3.9 \\
\hline
\end{tabular}




\begin{tabular}{|lllc|}
\hline Variable & Category & Frequency & $\begin{array}{c}\text { Percent } \\
(\%)\end{array}$ \\
\hline \multirow{2}{*}{ Know estrus detection } & Concentrate + grazing & 206 & 53.6 \\
\hline $\begin{array}{l}\text { Concentrate +roughage + } \\
\text { grazing }\end{array}$ & 10 & 2.6 \\
\hline Roughage + grazing & 105 & 27.3 \\
\hline Artificial insemination & yes & 30 & 7.8 \\
\cline { 2 - 4 } & No & 354 & 92.2 \\
\hline & Yes & 198 & 51.6 \\
\cline { 2 - 4 } & No & 102 & 26.6 \\
\cline { 2 - 4 } & Missing & 84 & 21.9 \\
\hline
\end{tabular}

\section{Major animal problem}

The largest problem they faced for their animals mentioned by the respondents ( $92 \%$ ) were shortage (expensiveness) of feed followed by disease problem (3\%) and unavailability of vaccine (1\%) (Figure 2).

\section{Perception of the society about the major infectious and zoonotic disease}

Rabies: About 9.6.6\% of respondents are aware of Rabies. They all well have known as that Rabies was transmitted by dog-bites. The awareness level of the respondent about Rabies indicates that its transmission through dog bites was a well-known fact. The knowledge of Rabies as a zoonotic disease was $96.6 \%$ (Table 3 ).

Anthrax: Anthrax was known about $33.03 \%$ of respondents and the transmission route mentioned by the respondent $43.3 \%$ was ingestion.

Tuberculosis: About only $5.2 \%$ of respondents had known Tuberculosis. The knowledge and awareness of Tuberculosis as a zoonotic disease in the respondents interviewed was very low.

Foot and mouth disease: Of the total respondents only $0.3 \%$ of them know about foot and mouth disease.

Trypanosomiasis:The overall proportion of respondents that know Trypanosomiasis was $0.6 \%$, few of them described Trypanosomiasis as a zoonotic disease that transmits to humans. 
Table 3

perception on infectious and zoonotic disease

\begin{tabular}{|c|c|c|c|}
\hline Variables & Category & number & $\begin{array}{l}\text { Percent } \\
(\%)\end{array}$ \\
\hline \multirow[t]{2}{*}{ Perception on animal disease } & Yes & 372 & 96.9 \\
\hline & No & 12 & 3.1 \\
\hline \multirow[t]{6}{*}{ If yes mention them } & Rabies & 233 & 60.7 \\
\hline & Anthrax & 98 & 25.5 \\
\hline & Rabies+ Anthrax & 27 & 7 \\
\hline & Rabies+Anthrax+TB & 14 & 3.6 \\
\hline & Rabies+Anthrax+FMD & 372 & 96.9 \\
\hline & system & 12 & 3.1 \\
\hline \multirow[t]{2}{*}{ Do u know their transmission } & Yes & 369 & 96.1 \\
\hline & No & 15 & 3.9 \\
\hline \multirow[t]{6}{*}{ How } & Biting & 199 & 50.5 \\
\hline & Biting +touching saliva & 57 & 14.7 \\
\hline & Biting + ingestion & 61 & 15.9 \\
\hline & Biting+ingestion+inhalation & 1 & 0.3 \\
\hline & biting don't know & 51 & 13.3 \\
\hline & system & 15 & 3. \\
\hline \multirow{2}{*}{$\begin{array}{l}\text { Have u ever infected or you know someone } \\
\text { infected by zoonotic disease }\end{array}$} & Yes & 112 & 29.2 \\
\hline & No & 272 & 70.8 \\
\hline \multirow[t]{2}{*}{ Do you know TB is zoonotic } & Yes & 20 & 5.2 \\
\hline & No & 364 & 94.8 \\
\hline \multirow[t]{2}{*}{ Do you know Rabies is zoonotic } & Yes & 371 & 96.6 \\
\hline & No & 13 & 3.4 \\
\hline
\end{tabular}

\section{Practical assessment of the respondent about veterinary clinic, vaccination \& slaughter house}


All of the respondents agreed to treat their animal when they get sick out of which $96.4 \%$ of them have brought their animal into the veterinary clinic, while still, 3.6\% prefers to use traditional medicine to cure the diseased animal. Regarding vaccination more than half of the respondents (63.5\%) fail to vaccinate their animals regularly and (83.6\%) have lack information/awareness about its importance.

Based on questions raised concerning the practical assessment of participants in the questionnaire, almost all 364 (94.8\%) of the respondents have the habit of consuming raw meat and the majority of them practiced $(99.2 \%)$ backyard slaughter in their home. In addition $360(93.8 \%)$ of them consume raw milk (Table 4). 
Table 4

Practical assessment of the respondent about veterinary clinic, vaccination \& slaughterhouse

\begin{tabular}{|c|c|c|}
\hline Variables & number & Percentage (\%) \\
\hline Do you treat your animal & - & - \\
\hline Yes & 100 & 100 \\
\hline No & - & - \\
\hline If yes what measure do you take & - & - \\
\hline Treat with traditional medicine & 14 & 3.6 \\
\hline Sell them & - & \\
\hline Bring to the vet clinic & 370 & 96.4 \\
\hline Do you take your animal to the vet clinic quickly once it becomes sick & - & - \\
\hline Yes & 100 & \\
\hline No & - & \\
\hline Who bring the animal to the clinic & - & - \\
\hline Father & 365 & 95. \\
\hline Mother & 19 & 4.9 \\
\hline Do you have information about vaccination and their importance & - & - \\
\hline Yes & 63 & 16.4 \\
\hline No & 321 & 83.6 \\
\hline Do you vaccinate your animal regularly & - & - \\
\hline Yes & 140 & 36.5 \\
\hline No & 244 & 63.5 \\
\hline Do you know the importance of slaughterhouse (Abattoir) & - & - \\
\hline Yes & 95 & 24.8 \\
\hline No & 289 & 75.2 \\
\hline During holy day where you slaughter your animal & - & - \\
\hline Backyard & 381 & 99.2 \\
\hline Abattoir & 3 & 0.8 \\
\hline Do you consume raw milk or meat & - & - \\
\hline Meat & 4 & 1 \\
\hline
\end{tabular}




\begin{tabular}{|lll|}
\hline Variables & number & Percentage (\%) \\
\hline Milk & 1 & 0.3 \\
Both & 360 & 93.8 \\
None & 19 & 4.9 \\
\hline
\end{tabular}

\section{Evaluation of factors affecting KAP on Veterinary Extension Service}

From Table $5 \mathrm{KAP}$ of the participant were evaluated based on their demography include their sex, age, education level, occupation, and marital status. The result showed that knowledge-related vaccination male participants had better knowledge than females and participants who attained secondary and college had better awareness and perception on the advantage of vaccination this association was statistically significant $(P<0.05)$. The current study also revealed that there is significant variation among the respondent $(P<0.05)$ towards the zoonotic disease of Rabies in which widowed and illiterate had lower knowledge and awareness (Table 6). 
Table 5

Factors associated with awareness towards animal vaccination among study participants

\begin{tabular}{|c|c|c|c|c|c|c|}
\hline \multirow[t]{2}{*}{ Variables } & \multirow[t]{2}{*}{ Category } & \multicolumn{3}{|c|}{ Aware } & \multirow[t]{2}{*}{$x^{2}$ value } & \multirow[t]{2}{*}{ P-value } \\
\hline & & Yes & No & Total & & \\
\hline \multirow[t]{3}{*}{ Owner Gender } & Male & 120 & 180 & 300 & \multirow[t]{3}{*}{7.426} & \multirow[t]{3}{*}{0.006} \\
\hline & Female & 20 & 64 & 84 & & \\
\hline & Total & 140 & 244 & 384 & & \\
\hline \multirow[t]{6}{*}{ Kebele } & Kebele 01 & 15 & 6 & 21 & \multirow[t]{6}{*}{17.947} & \multirow[t]{6}{*}{0.001} \\
\hline & Kebele 02 & 18 & 20 & 38 & & \\
\hline & Kebele 03 & 20 & 25 & 45 & & \\
\hline & kebele 04 & 10 & 19 & 29 & & \\
\hline & Around Robe & 77 & 174 & 251 & & \\
\hline & Total & 140 & 244 & 384 & & \\
\hline \multirow[t]{6}{*}{ Educational status } & Illiterate & 25 & 54 & 79 & \multirow[t]{6}{*}{12.206} & \multirow[t]{6}{*}{0.016} \\
\hline & Read and write & 40 & 69 & 109 & & \\
\hline & Primary school & 33 & 82 & 115 & & \\
\hline & Secondary school & 32 & 31 & 63 & & \\
\hline & College and University & 10 & 8 & 18 & & \\
\hline & Total & 140 & 244 & 384 & & \\
\hline \multirow[t]{7}{*}{ Occupation } & Farmer & 57 & 97 & 154 & \multirow[t]{7}{*}{21.311} & \multirow[t]{7}{*}{0.001} \\
\hline & Merchant & 51 & 77 & 128 & & \\
\hline & Employee & 12 & 5 & 17 & & \\
\hline & Housewife & 3 & 26 & 29 & & \\
\hline & Daily labor & 17 & 33 & 50 & & \\
\hline & Students & 0 & 6 & 6 & & \\
\hline & Total & 140 & 244 & 384 & & \\
\hline
\end{tabular}


Table 6

Factors associated with knowledge towards zoonotic disease among study participants

\begin{tabular}{|c|c|c|c|c|c|c|}
\hline \multirow[t]{2}{*}{ Variables } & \multirow[t]{2}{*}{ Category } & \multicolumn{3}{|c|}{$\begin{array}{l}\text { Knowledge on Rabies as zoonotic } \\
\text { disease }\end{array}$} & \multirow[t]{2}{*}{$\begin{array}{l}\chi 2 \\
\text { value }\end{array}$} & \multirow[t]{2}{*}{$\begin{array}{l}\mathrm{P}- \\
\text { value }\end{array}$} \\
\hline & & Yes & No & Total & & \\
\hline \multirow[t]{3}{*}{ Owner Gender } & Male & 298 & 2 & 300 & \multirow[t]{3}{*}{30.993} & \multirow[t]{3}{*}{0.0001} \\
\hline & Female & 73 & 11 & 84 & & \\
\hline & Total & 371 & 13 & 384 & & \\
\hline \multirow[t]{4}{*}{ Age Category } & less than 20 & 9 & 0 & 9 & \multirow[t]{4}{*}{13.864} & \multirow[t]{4}{*}{0.001} \\
\hline & 20 to 40 & 212 & 1 & 213 & & \\
\hline & Above 40 & 150 & 12 & 162 & & \\
\hline & Total & 371 & 13 & 384 & & \\
\hline \multirow[t]{5}{*}{ Marital status } & Married & 237 & 10 & 247 & \multirow[t]{5}{*}{26.439} & \multirow[t]{5}{*}{0.0001} \\
\hline & Divorced & 18 & 0 & 18 & & \\
\hline & Unmarried & 109 & 0 & 10 & & \\
\hline & widowed & 7 & 3 & 109 & & \\
\hline & Total & 371 & 13 & 384 & & \\
\hline \multirow{6}{*}{$\begin{array}{l}\text { Educational } \\
\text { status }\end{array}$} & Illiterate & 69 & 10 & 79 & \multirow[t]{6}{*}{26.633} & \multirow[t]{6}{*}{0.0001} \\
\hline & Read and write & 107 & 2 & 109 & & \\
\hline & Primary school & 114 & 1 & 115 & & \\
\hline & Secondary school & 63 & 0 & 63 & & \\
\hline & $\begin{array}{l}\text { College and } \\
\text { University }\end{array}$ & 18 & 0 & 18 & & \\
\hline & Total & 371 & 13 & 384 & & \\
\hline
\end{tabular}

\section{Discussion}

Based on the questionnaire surveyed employed about animal production, animal management, animal health and how to control the animal disease as well as the veterinary health extension services in the study area the result revealed that the majority of the respondent had their own local and more than one species at a time. Regarding training and presence of consultants, highest number of respondents explains the absence of good and accessible training about animal production and health. Respondents confirmed that shortage (expensiveness) of feed and presence of diseases are the front constraints of their livestock production and had a knowledge of estrous cycle and user of artificial insemination as well 
as they used natural pastures and frequently feed supplement. Almost the entire respondent argued that the presence of animal extension services.

The current study revealed that the knowledge of the respondent in the study area about zoonotic disease is good in which comparable finding was observed by Girma et al. [27] who indicated that all respondents knew animals' disease can also affect humans. The most frequently known zoonotic diseases among the respondents in the study area were Rabies (96.6\%), followed by Anthrax (33.07\%), Tuberculosis (4.52\%), Trypanosomiasis (0.6\%) and foot and mouth disease (0.3\%). A similar finding has been reported in other parts of the country [28].

In the current study about (96.1\%) respondents have a high level of knowledge about Rabies that the modes of transmission mentioned by respondents were bites (51.8\%), bites and contact with saliva (14.7\%). The current result agrees with the previous finding from Shashemene [29] and the finding in Dodola Town that was reported by Gezmu et al., [30]. In contrast, there is a low level of awareness about the zoonotic nature of Tuberculosis (4.2\%) as compared to the report of Girma et al., [27] who indicated that respondents in Addis Ababa mentioned bovine Tuberculosis (88.54\%). The present finding is also lower than the finding by T. Dawit et al., [31] Jimma town who reported that the perception on the dog bite reaches $94.3 \%$. The difference comes out due to information might be acquired more easily through media and human health extension service agents than in the current study area and extension service in the study area is low.

Concerning the treatment, they prefer for their animal about (3.6\%) of the study participants use modern (veterinary clinic) in which had high variation with the report of Digafe et al., [32] studies conducted in and around Gondar town, reported about (62.2\%) of the study participants had strong beliefs in traditional medicine.

Regarding consumption of animal products like raw milk and raw meat, the present study revealed that the majority of participants (93.8\%) and (94.8\%) were used respectively, similar findings were observed by Wario et al., [33] with (89.8\%) and (99\%) respectively. According to the current study, the perception of vaccination among study participants includes gender, age, kebele, educational status and occupation there was significantly $(P<0.05)$ associated. Concerning the perception of Rabies as a zoonotic disease, there was a significantly $(P<0.05)$ different level of awareness among the different respondent groups which can imply that they have different levels of knowledge about zoonotic perception of Rabies and transmission to humans by biting of dog. In conclusion, the present study indicated that all the stakeholders' should have to fulfill their responsibility to improve and distribute extension service among the community and awareness creation and training programs of Zoonotic disease transmission, treatment, prevention, and control should be provided to communities.

\section{Conclusion And Reccomandation}

The study shows that veterinarians were not much involved in veterinary extension services. As a result, the awareness of animal owners about animal production improvement and animal health and zoonotic 
risks of infectious animal diseases was not satisfactory. This is reflected by the malpractice of animal owners which exposes them to zoonotic diseases like consuming raw milk and raw meat and backyard animal slaughtering practices. There was no one-health approach implemented so far. Hence, to control zoonotic disease veterinary extension services and disease control programs need to be implemented. Scheduled animal vaccination, raising community awareness about sanitary conditions and disposal of food of animal origin, understanding the epidemiology of disease and transmission and prevention should be applied. On top of this, multispectral collaborative one-health efforts need to be made among veterinarians and public health specialists to combat zoonotic disease.

\section{Declarations}

\section{Acknowledgments}

The authors extend gratitude to Hawassa University Faculty of Veterinary Medicine for the provision of academic guidance and materials used to write this manuscript. The authors are also thankful to the Robe veterinary clinic officers, animal owners and other study participants.

\section{Funding}

This work was partially supported by the Faculty of Veterinary Medicine of Hawassa University, Ethiopia.

\section{Availability of data and materials}

The data supporting the findings are presented in the manuscript. The corresponding author can also be reached for any data inquiry.

\section{Authors' contributions}

SAN was involved in the conception of the study, supervision, editing and approval of the manuscript. AA was involved in sample collection, laboratory investigation, data analysis and preparation of the draft manuscript. All authors read and approved the final manuscript.

\section{Ethics approval and consent to participate}

The study was approved by the research proposal review committee of the faculty of veterinary medicine, Hawassa University. Written informed consent was obtained for the questionnaires interview and the study was carried out in accordance with relevant guidelines and regulations.

\section{Consent for publication}

Not applicable.

\section{Competing interests}

The authors declare that they have no competing interests. 


\section{References}

1. Katz E, Armin B: Innovative approaches to financing extension for agriculture and natural resource management: conceptual considerations and analysis of experience. Economics Corpus ID: 1541742252014.

2. Davidson A, Munir AP, Tanvir A: Dilemmas of agricultural extension in Pakistan: Food for thought. Agricultural Research \& Extension Network 2001(116).

3. Muyanga M, Jayne TS: Private Agricultural Extension System in Kenya: Practice and Policy Lessons. The Journal of Agricultural Education and Extension 2008, 14(2):111-124.

4. Fliegel F: Diffusion Research in Rural Sociology. The Record and Prospects for the Future. Current Events and Issues/Society 1992, 1:152.

5. Sultan AN: Animal Health Extension and Pastoralism: A module Prepared and Submitted to Wollega University, Collage of Medical and HealthScience, School of Veterinary Medicine. Nekemte, Ethiopia. 2014.

6. Lindahl JF, Grace D: The consequences of human actions on risks for infectious diseases: a review. Infect Ecol Epidemiol 2015, 5:30048-30048.

7. Grace D, Mutua F, Ochungo P, Kruska R, Jones K, Brierley L, Lapar L, Said M, Herrero M, Phuc P et al: Mapping of poverty and likely zoonoses hotspots. Zoonoses Project 4. Report to the UK Department for International Development. Nairobi, Kenya: ILRI. 2012.

8. CSA: Central statistical agency (CSA). Agricultural sample survey 2016/2017 (2009 E.C). volume I report on area and production of major crops (private peasant holdings, Meher season), Addis Ababa. 2017.

9. FAO: The future of Livestock in Ethiopia: Opportunities and challenges in the face of uncertainty. Rome. Italy. Licence: CC BY-NC-SA 30 IGO 2019:48.

10. WHO: Managing zoonotic public health risks at the human-animal-ecosystem interface. Food safety and zoonoses 2011.

11. McDermott J, Grace D: Agriculture-associated diseases: adapting agriculture to improve human health. In Reshaping agriculture for nutrition and health (S. Fan \& R. Pandya-Lorch, eds). 2020 Conference Book. International Food Policy Research Institute (IFPRI), Washington, DC, United States of America, 103-112. 2012.

12. Murphy SC, Negron ME, Pieracci E, Deressa A, Bekele W, Regassa F, Wassie BA, Afera B, Hajito KW, Walelign E et al: One Health collaborations for zoonotic disease control in Ethiopia: -EN- -FR- Les collaborations Une seule santé pour lutter contre les maladies zoonotiques en Éthiopie -ES-

Actividades de colaboración en clave de Una sola salud para combatir enfermedades zoonóticas en Etiopía. Revue Scientifique et Technique de I'OIE 2019, 38:51-60.

13. Venkatasubramanian V, Rao SVN: Livestock Extension Education. ICAR, New Delhi. 2012.

14. OPCDP: Oromia Pastoral Area Development Commission: Community-based animal health workers (CAHWs) Training Manual. Oromia, Ethiopia. 2004. 
15. Taylor LH, Latham SM, Woolhouse ME: Risk factors for human disease emergence. Philos Trans $R$ Soc Lond B Biol Sci 2001, 356(1411):983-989.

16. Woolhouse ME, Gowtage-Sequeria S: Host range and emerging and reemerging pathogens. Emerg Infect Dis 2005, 11(12):1842-1847.

17. Jones KE, Patel NG, Levy MA, Storeygard A, Balk D, Gittleman JL, Daszak P: Global trends in emerging infectious diseases. Nature 2008, 451(7181):990-993.

18. Pieracci EG, Hall AJ, Gharpure R, Haile A, Walelign E, Deressa A, Bahiru G, Kibebe M, Walke H, Ermias B: Prioritizing zoonotic diseases in Ethiopia using a one health approach. One Health 2016, 2:131135.

19. Grace D, Mutua F, Ochungo P, Kruska R, Jones K, Brierley L, Lapar L, Said M, Herrero M, Phuc PM et al: Mapping of poverty and likely zoonoses hotspots. Zoonoses Project 4. Report to the UK Department for International Development. Nairobi, Kenya: ILRI. 2012.

20. Yalemebrat N, Tilahun B, Moa M: Assessment of public knowledge, attitude and practices towards rabies in Debark Woreda, North Gondar, Ethiopia. J Vet Med Anim Health 2016, 8(11):183-192.

21. Gustafson CR, VanWormer E, Kazwala R, Makweta A, Paul G, Smith W, Mazet JAK: Educating pastoralists and extension officers on diverse livestock diseases in a changing environment in Tanzania. Pastoralism 2015, 5(1):1.

22. Organization W: Research priorities for zoonoses and marginalized infections. 2012:ix-xi, 1.

23. Oromia_Kelel: Physical and socio-economic profiles of 180 districts of Oromiya Region. Physical Planning Department. Oromia Kelel, Ethiopia. 2000:402.

24. Duressa T, Mohammed A, Fayissa G, Tufa LT, Siraj K: Comparative Analysis of lodine Concentration in Water, Soil, Cereals and Table Salt of Horaboka, Mio and Besaso Towns of Bale Robe, South East Ethiopia. 2014:27-33.

25. Thrusfield MV: Veterinary epidemiology. Oxford; Ames, lowa: Blackwell Science; 2007.

26. Tomley FM, Shirley MW: Livestock infectious diseases and zoonoses. Philosophical transactions of the Royal Society of London Series B, Biological sciences 2009, 364(1530):2637-2642.

27. Girma S, Zewde G, Tafess K, Jibat T: Assessment of awareness on food borne zoonosis and its relation with Veterinary Public Health Services in and around Addis Ababa, Ethiopia. Ethiop Vet $J$ 2012, 6(1):15-22.

28. Neja SA: Study on the Major Cattle Health and Production Constraints in and Around Haramaya Town, Ethiopia. Journal of Biology, Agriculture and Healthcare 2020, 10:1-9.

29. Abda S, Mamo G, Worku A, Ameni G: Preliminary study on avian tuberculosis and associated risks in domestic chickens at Shashemene district, Ethiopia. Journal of Biology and Medical Sciences 2015, 3:13-23.

30. Gezmu M, Bsrat A, Mekuria A: Assessment of community Knowledge, attitude and practice on zoonotic disease in and around Dodola town, west Arsi zone, Ethiopia. 2017. 
31. Semu D, Fekede D, Tigre W, Regassa A, Fekadu A: Perception of the public on the common zoonotic diseases in Jimma, Southwestern Ethiopia. International Journal of Medicine and Medical Sciences 2013, 5:279-285.

32. Digafe RT, Kifelew LG, Mechesso AF: Knowledge, attitudes and practices towards rabies: questionnaire survey in rural household heads of Gondar Zuria District, Ethiopia. BMC research notes 2015, 8(1):1-7.

33. Zewdie W, Wario E, Tehetna A: Assessment of community awareness on common zoonotic disease in and around Yabello District of Oromia regional state, Ethiopia. Multidisciplinary Advances in Veterinary Science 2018, 2(4):388-394.

\section{Figures}

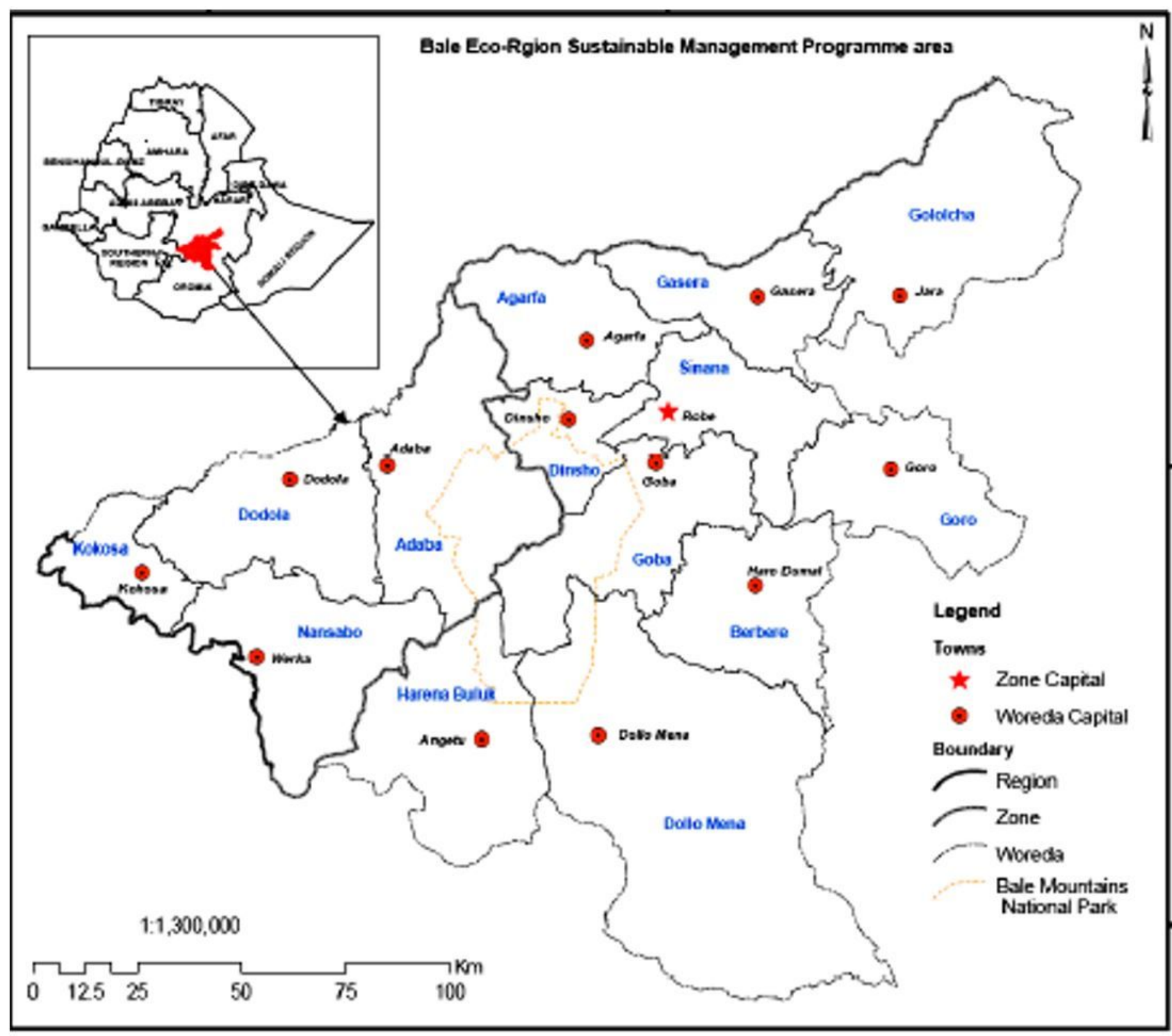


Figure 1

Map of Bale Zone. Source: Duressa et al. [24].

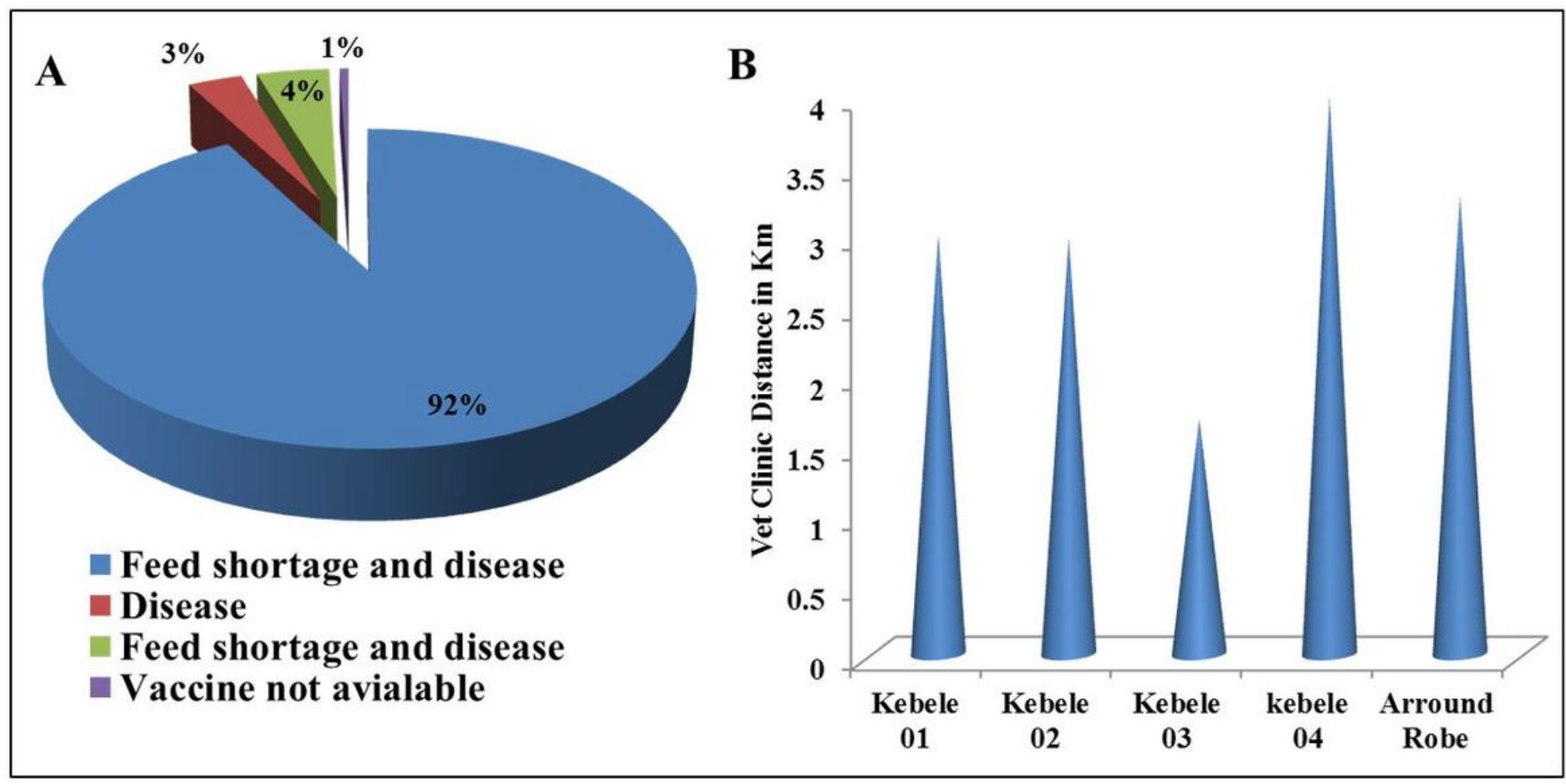

Figure 2

Major animal production and health constraints in the area. A) The Pie-chart was drawn using the percent of respondents who selected each constraint. B) The Bar-chart shows the pattern of veterinary clinic distance from the residents. The average veterinary clinic distance from the farmer's resident was calculated. 